\title{
Religious Harmony Construct Amid A Plural Community in East Java
}

\author{
Dina Mardiana \\ Fakultas Agama Islam, Universitas Muhammadiyah Malang, Indonesia \\ email: dinamardiana@umm.ac.id \\ Muhammad Yusuf \\ Fakultas Agama Islam, Universitas Muhammadiyah Malang, Indonesia \\ email:m.yusuf@umm.ac.id \\ Asyraf Isyraqi Jamil \\ Academy of Islamic Studies, University of Malaya, Malaysia \\ email: isyraqi@um.edu.my
}

\begin{abstract}
This study examined the harmonization of five religions (Islam, Catholicism, Protestantism, Hinduism, and Buddhism) that are adhered to by the people of Mojorejo Village, Batu, East Java. This village has an important role, as it becomes the first area in Batu, East Java - that implement and develop the concept of religious pluralism and harmonization in one village area thus it has been awarded as "A Village that is Aware of Religious Harmony" from the government of Batu. Therefore, this study aimed to understand the constructs of religious harmony that have been successfully established in Mojorejo Village, Batu, East Java. The theory underlying this study is Nurcholis Madjid's theory of humanist pluralism. This study used a qualitative approach to produce descriptive data in the form of oral, written, and observable behavior. Through three data collection methods (observation, in-depth interview, a study of documents), this study concludes that the religious harmony construct of the Mojorejo Village
\end{abstract}

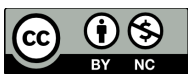

DOI: $10.19105 /$ karsa.v28i2.3777 
community is established from a pattern of accustoming mutual respect among villagers which is carried out both naturally and sustainably. This continuity manifests through cooperation in three ways: religious, social, and cultural cooperation so that it can lead to the emerge of perspectives, ideas, and a social environment capable of maintaining and preserving religious plurality in harmony. Therefore, the application of religious harmony in Mojorejo Village, Batu, East Java can be used as an alternative solution for other areas in locating and facilitating religious plurality so that it remains harmonious amid a pluralistic community.

[Riset ini menelaah tentang harmonisasi lima agama (Islam, Katolik, Protestan, Hindu, dan Budha) yang dianut masyarakat Desa Mojorejo Kota Batu Jawa Timur. Desa ini memiliki peran penting, sebab menjadi kawasan pertama di Kota Batu yang menerapkan dan mengembangkan konsep pluralisme agama dan harmonisasi dalam satu wilayah desa hingga berhasil mendapat penghargaan sebagai "Desa Sadar Kerukunan Umat Beragama" dari pemerintah Kota Batu. Karenanya, riset ini bertujuan untuk memahami konstruk harmoni keagamaan yang telah berhasil dibangun di Desa Mojorejo Kota Batu. Teori yang melandasi kajian ini ialah teori pluralisme humanis Nurcholish Madjid. Riset ini menggunakan pendekatan kualitatif untuk menghasilkan data deskriptif berupa data lisan, tertulis, maupun perilaku yang dapat diamati. Melalui tiga metode pengumpulan data (observation, in-dept interview, study of documents), riset ini menyimpulkan bahwa konstruk harmoni keagamaan masyarakat Desa Mojorejo dibangun dari pola pembiasaan sikap saling menghormati diantara para warga desa yang dilakukan secara natural sekaligus juga berkelanjutan. Kontinuitas ini mewujud melalui kerjasama dalam tiga hal: kerjasama keagamaan, sosial, serta budaya sehingga mampu bermuara pada lahirnya cara pandang, ide, gagasan, hingga lingkungan sosial yang mampu merawat pluralitas agama secara harmonis. Dengan demikian, penerapan harmoni keagamaan Desa Mojorejo Kota Batu ini dapat dijadikan solusi alternatif bagi wilayah-wilayah lain dalam mendudukkan dan memfasilitasi pluralitas agama sehingga tetap harmonis di tengah kemajemukan masyarakat.]

Keywords: Buddhism; Christian; Hinduism; Islam; pluralism; religious harmony

\section{Introduction}

The plurality of religions, which is one of the characteristics of

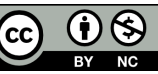

DOI: $10.19105 /$ karsa.v28i2.3777 
the plurality of the Indonesian community, needs to always be maintained for its existence, to make the interreligious relations within it can always run in harmony. It is reasonable then that the discourses on the theme of religious harmony ${ }^{123}$ and the dynamics of tolerance that accompany it, show an increasing trend in academia so that it can produce a variety of researches, starting from the concept of religious tolerance from the perspective of the al-Qur' $\mathrm{an}^{4}$, the foundation of tolerance in Islam ${ }^{5}$, the concept of ideals of religious tolerance ${ }^{7}$, the phenomenon of religious diversity as a sunnatullah ${ }^{8}$, to researches on religious tolerance which is examined through various scientific disciplines such as the Psychology of Religion ${ }^{9}$ and Archeology. ${ }^{10}$ The emergence of these studies indicates that the phenomenon of diversity

\footnotetext{
${ }^{1}$ Abu Rokhmad, "The Role of Inter-Religious Harmony Forum in Maintaining The Harmony of Religious Life in Plural Society," The Social Sciences 11, no. 21 (2016): 5052-59, https://doi.org/10.3923/sscience.2016.5052.5059.

${ }^{2}$ Francisco Soares and I Ketut Sudarsana, "Religious Harmony Among Senior High School Students Multicultural Education Case Study in the Cova-Lima District of East Timor," Vidyottama Sanatana: International Journal of Hindu Science and Religious Studies 2, no. 1 (2018): 154-62, https://doi.org/10.25078/ijhsrs.v2i1.522.

$3 \mathrm{Ni}$ Luh Aryani, "Implementation of Communication Ethics in Building Social Harmony," International Journal of Social Sciences and Humanities 2, no. 1 (2018): 147-56, https://doi.org/10.29332/ijssh.v2n1.105.

${ }^{4}$ Muhamad Ridho Dinata, "Konsep Toleransi Beragama Dalam Tafsir Al-Qur'an Tematik Karya Tim Departemen Agama Republik Indonesia," Esensia 13, no. 1 (2012): 85-108.

5 Toto Suryana, "Konsep Dan Aktualisasi Kerukunan Antar Umat Beragama," Pendidikan Agama Islam -Ta'lim 9, no. 2 (2011): 127-36.

6 Abu Bakar, "Konsep Toleransi Dan Kebebasan Beragama," Toleransi: Media Komunikasi Umat Bergama 7, no. 2 (2015): 123-31.

${ }^{7}$ Casram, "Membangun Sikap Toleransi Beragama," Wawasan: Jurnal Ilmiah Agama Dan Sosial Budaya 1, no. 2 (2016): 187-98.

${ }^{8}$ R. Fidiyani, “Kerukunan Umat Beragama Di Indonesia ( Belajar Keharomonisan Dan Toleransi Umat Beragama Di Desa Cikakak, Kec. Wangon, Kab. Banyumas)," Jurnal Dinamika Hukum 13, no. 3 (2013): 468-82.

9 Roni Ismail, "Konsep Toleransi Dalam Psikologi Agama (Tinjauan Kematangan Beragama)," Religi VIII, no. 1 (2012): 1-12, https://doi.org/10.14421/rejusta.2012. $\% 25 \mathrm{x}$.

${ }^{10}$ Hariani Santiko, "Toleransi Beragama Dan Karakter Bangsa: Perspektif Arkeologi," Sejarah Dan Budaya 7, no. 1 (2013): 1-8.
}

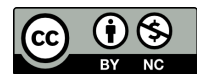

DOI: $10.19105 /$ karsa.v28i2.3777 
that is present as a reality amid the plurality of community in Indonesia has received a positive response in the world of academia thus makes it interesting to be studied and analyzed.

The actualization of this theme is increasingly important when the fact that the plural diversity of the community in the aspects of religion and belief confronts its paradox in terms of the issue of intolerance which becomes the theme of the research, for example, the research of Wijaya et al., which raises the discourse of religious intolerance in local newspapers ${ }^{11}$, as well as the discourse of religious intolerance that arises among students. ${ }^{12}$ This means, the plurality of community in the aspect of religion that is believed, indirectly has two implications, namely the concrete harmonization of religious teachings in the form of religious tolerance behaviour, and vice versa - if this diversity is not accompanied by social maturity in religion, it will have an impact on the emergence of intolerant behaviour in some religious adherents/believers amid the plurality of community. This becomes a problem that must be immediately sought for a solution through multiperspective scientific research to obtain scientific findings that can support the solid construct of religious harmonization amid community.

The discourse on strengthening religious harmonization amid a plural community that manifests in an attitude of religious tolerance - is born and proclaimed by external parties, both government and NonGovernmental Organizations (NGOs) based on two arguments: First, the plurality of the Indonesian community is a form of wealth of the nation's cultural treasures which needs to be constantly cared for and used to support the unity of the nation. Second, efforts to create tolerance among religious adherents or believers are the responsibility of all elements of the nation, so there is a need for collaboration between the government - as formal juridical policymakers - and the community as

\footnotetext{
${ }^{11}$ M. Wijaya, S. H. B., Mursito, \& Anshori, "Media Massa Dan Intoleransi Beragama (Studi Kasus Tentang Wacana Intoleransi Beragama Pada Surat Kabar Lokal Di Kota Surakarta Tahun 2012)," Jurnal Komunikasi Massa 6, no. 2 (2013): 175-88.

${ }^{12}$ Qowaid, "Gejala Intoleransi Beragama Di Kalangan Peserta Didik Dan Upaya Penanggulangannya Melalui Pendidikan Agama Islam Di Sekolah,” Dialog: Jurnal Penelitian Dan Kajian Keagamaan 36, no. 1 (2013): 71-86.
}

\section{(c) $\underset{\mathrm{BY}}{\mathrm{Br}}(\mathrm{NC}$}

DOI: $10.19105 /$ karsa.v28i2.3777 
the subject of social institutions. So that, at the level of idealism, religious harmony that is born from religious tolerance should be established through the active participation of all members of the religious community based on the common values of togetherness, respecting the religious doctrines and rituals of each religion, and avoiding exclusivity in religion.

The phenomenon of various religions that are present and embraced amid a plural Indonesian community is a description of the social reality that continues to grow along with the development of social institutions in the society itself, like the religious harmony that grows in the community of Mojorejo Village, Batu, East Java. Interestingly, at the end of November 2019, this village managed to appreciate the Batu government in the form of an award as "A Village that is Aware of Religious Harmony". ${ }^{13}$ This success is a proud achievement, considering that Batu has a relatively high community heterogeneity typology. The following is data from the Statistics of Batu Municipality as of 2017: ${ }^{14}$

Table 1

Total Population by District and Religion in Batu

\begin{tabular}{|l|c|c|c|c|c|c|c|}
\hline District & Islam & $\begin{array}{c}\text { Protest } \\
\text { antism }\end{array}$ & $\begin{array}{c}\text { Catholic } \\
\text { ism }\end{array}$ & $\begin{array}{c}\text { Hind } \\
\text { uism }\end{array}$ & $\begin{array}{c}\text { Budd } \\
\text { hism }\end{array}$ & $\begin{array}{c}\text { Kong } \\
\text { hucu }\end{array}$ & $\begin{array}{c}\text { Othe } \\
\text { rs }\end{array}$ \\
\hline $\begin{array}{l}010 \\
\text { Batu }\end{array}$ & 94090 & 5333 & 2298 & 61 & 357 & 5 & 84 \\
\hline $\begin{array}{l}020 \\
\text { Junrejo }\end{array}$ & 52923 & 2244 & 376 & 77 & 214 & - & 54 \\
\hline
\end{tabular}

${ }^{13}$ U. Afrian, "FKUB Launching Desa Sadar Kerukunan Beragama," Last modified November 28, 2019, https://radarmalang.id/fkub-launching-desa-sadar-kerukunanber agama/.

14 "Jumlah Penduduk Menurut Kecamatan Dan Agama Yang Dianut di Kota Batu, 2017," Dinas Kependudukan dan Pencatatan Sipil, batukota.bps.go.id, updated October 2019, https://batukota.bps.go.id/statictable/2018/12/12/315/jumlahpendudukmenurut-kecamatan-dan-agama-yang-dianut-di-kota-batu-2017.html.

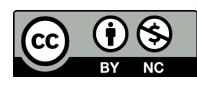

DOI: $10.19105 /$ karsa.v28i2.3777 


\begin{tabular}{|l|c|c|c|c|c|c|c|}
\hline $\begin{array}{l}\text { 030 } \\
\text { Bumiaji }\end{array}$ & 62466 & 774 & 217 & 276 & 17 & - & 28 \\
\hline Batu & 209479 & 8351 & 2891 & 414 & 588 & 5 & 166 \\
\hline
\end{tabular}

Source: Department of Population and Civil Registration Batu City (2017)

Sociologically, through these data, it appears that pluralism has become an empirical reality in Mojorejo Village, Batu, East Java. This can be seen in society's sociological condition, which is not only polarized through regional segmentation but has differentiation religion and belief. Therefore, this phenomenon becomes a basic assumption and an integral part of the phase of religious harmony - harmonization through tolerant behavior raised by each religious adherent in Mojorejo Village, Batu, East Java. The religious harmony which manifests in the emergence of inter-religious harmony is a fact that originates in the internalization of good theological-social values. This is where the understanding of the religious commitment that underlies the formation of religious tolerance becomes urgent to be interpreted and analyzed.

\section{Methods}

This article aimed to conduct a critical analysis that could parse or unravel the construction of religious commitment that underlies the emergence of religious tolerance and religious harmony in Mojorejo Village, Batu, East Java. Through the reconstruction of the meaning of religious commitment, it will have implications for the strengthening of the establishment of religious tolerance harmonization amid the plurality of the Indonesian community in general, and the Batu City community in particular.

The problem raised in this study focuses on how the religious harmony construct is established in Mojorejo village so that it can become the best sample area in the field of inter-religious tolerance in Batu, East Java. Therefore, this study used a qualitative approach with three data collection methods (observation, in-depth interview, a study of documents) to answer the focus of the problem. Furthermore, the data were analyzed using interactive model analysis techniques initiated by

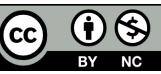

DOI: $10.19105 /$ karsa.v28i2.3777 
Miles Huberman and Saldana, namely: data collection, data condensation, data display, and verifying.

\section{Results}

\section{Demographic Description and Religious Pluralism}

Mojorejo Village is an area located in Batu, East Java Province, Indonesia. This village consists of 2 hamlets, namely Kajang Hamlet (consisting of 7 Rukun Warga [RW] and 14 Rukun Tetangga [RT]), and Ngadat Hamlet (consisting of $3 \mathrm{RW}$ and 10 RT). Mojorejo Village is 6 $\mathrm{km}$ from the Batu City government. Quantitatively, most people in this village adhere to Islam with a total of 4365 people, Protestants with 331 people, Buddhists with 286 people, Catholics with 13 people, and Hindu as many as one person. ${ }^{15}$ The fact of religious dynamics that can see through this number gives meaning to the importance of harmony between religions to always be cared for and guarded, amid society's existing plurality.

More specifically, the religious composition and number of worship places owned by Mojorejo Village can be seen in the table below:

Table 2

Total Population of Mojorejo Village and Owned

Places of Worship

\begin{tabular}{|l|l|l|l|l|}
\hline No & Religion & $\begin{array}{l}\text { Total } \\
\text { Population }\end{array}$ & $\begin{array}{l}\text { Worship } \\
\text { Places }\end{array}$ & Total \\
\hline 1 & Islam & 4365 & Mosque & 8 \\
\hline 2 & Catholicism & 13 & Mushalla & 13 \\
\hline 3 & Protestantism & 331 & Church & 2 \\
\hline 4 & Hinduism & 1 & Temple & 1 \\
\hline 5 & Buddhism & 286 & $T P Q$ & 8 \\
\hline
\end{tabular}

15 “Jumlah Penduduk Desa Mojorejo Dan Tempat Ibadah Yang Dimiliki," Last modified April 2020, Mojorejo village archives.

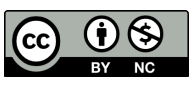

DOI: $10.19105 /$ karsa.v28i2.3777 


\begin{tabular}{|l|l|l|l|}
\hline Total & 4.996 & 5 & 32 \\
\hline
\end{tabular}

Source: Mojorejo Village Archives (2020)

The reality of religious plurality in Mojorejo Village, Batu, needs to be supported by an outstanding religious commitment among existing religious adherents. In answering and providing solutions to various religious communities' problems in Mojorejo Village, religious commitment is present to create harmony and tolerance between religious believers, which has often been carried out. The cultural heterogeneity that has long existed in Mojorejo Village, Batu in the form of a variety of varied religious traditions, as well as the variety of religious activities of each religion has received active participation, both by adherents of the concerned religion and adherents of other religions who live in the village area of Mojorejo. This can be seen, for example, in the annual religious rites in the form of interfaith prayers attended by all elements of the religious community in Mojorejo Village. At this moment, all religions in Mojorejo Village were present and prayed for the village's safety.

The narrative of religious plurality and the community's portrait in it - as in Mojorejo Village - which manifested in the emerge of various religious rites across religions, is only a concrete representation design of the image of a community in one region in Indonesia. The typology of relations between religious believers exists and has formulated through various field research with research locus in several other regions in Indonesia, as Fidiyani's research ${ }^{16}$ which targeted Banyumas Regency as her research locus on religious tolerance there, Jazadi who examines the cultural challenges in the Sumbawa region ${ }^{17}$, as well as

\footnotetext{
${ }^{16}$ Fidiyani, "Kerukunan Umat Beragama Di Indonesia ( Belajar Keharomonisan Dan Toleransi Umat Beragama Di Desa Cikakak, Kec. Wangon, Kab. Banyumas)."

${ }^{17}$ Iwan Jazadi, "The Concerns, Roots, and Challenges of Islamic Culture in Sumbawa and Their Implications for Implementing Halal Tourism," Karsa: Journal of Social and Islamic Culture 27, no. 1 (2019): 52-74, https://doi.org/10.19105/karsa.v27i1. 2299.
}

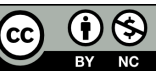

DOI: $10.19105 /$ karsa.v28i2.3777 
Pamungkas research which chose Buleleng as the research location. ${ }^{18}$ The research focus, which bases on the fact of religious plurality, is expected to lead to a more established dialogue of religious harmony in various regions in Indonesia.

\section{Discussion}

\section{The Design of Five Religions Harmonization}

Mojorejo Village is a region with an area of $2.081 \mathrm{~km}^{2}(175 \mathrm{Ha})$ located in a highland area in Batu, East Java, Indonesia. In de jure, this village has gone through the leadership phase of 12 village heads for a period of 79 years from 1942 to 2020. During these periods, this village has succeeded in maintaining the differentiation and plurality of its community so that it can produce religious harmony. The religious harmony that is buzzing in Mojorejo Village and makes it able to place it as the "Village of Religious Harmony", does not just appear instantly, but it manifests through the design of social constructs that are carried out synergistically and continuously by various elements of the community in it.

Referring to the thesis in the humanist pluralism theory of Nurcholis Madjid which states that inclusiveness and humanist character are the roots of the construction of religious pluralism ${ }^{19}$, the phenomenon of religious diversity and beliefs in Mojorejo Village is one concrete example of this theory. The religious component is interpreted inclusively, not only as an abstract formula for the appreciation of a belief itself. The design of inclusiveness can be seen from the expression of religious teachings through real life in respecting the beliefs of others; a pattern of coexistence with various adherents/believers of different religions. Next, the humanist character of the Mojorejo Village community is designed in a community pattern that upholds the values

18 Cahyo Pamungkas, "Toleransi Beragama Dalam Praktik Sosial: Studi Kasus Hubungan Mayoritas Dan Minoritas Agama Di Kabupaten Buleleng," Epistemé: Jurnal Pengembangan Ilmu Keislaman 9, no. 2 (2014): 285-316.

19 Nurcholish Madjid, Pluralitas Agama: Kerukunan Dalam Keragaman (Jakarta: Kompas, 2001),vii.

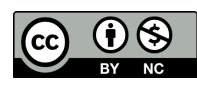

DOI: $10.19105 /$ karsa.v28i2.3777 
of cooperation, as stated in the statement of the Head of Mojorejo Village:

"Our people here are accustomed to the style of working together, gethuk tular if there are neighbors who need help. In village clean-up events, for example, our villagers independently help each other organize these events voluntarily. Likewise, during interfaith prayer moments, followers of five different religions should pray together according to their beliefs. All join in praying for the safety of our village." 20

The religious harmonization design of the five religions in Mojorejo Village is inseparable from the concept of the term harmonization which means harmony and an effort to find harmony. ${ }^{21}$ From a philosophical aspect, it can be seen as a form of unification and cooperation of various factors that give birth to a unity that is noble in nature. The researcher analyzed the design of religious harmony in Mojorejo Village as a manifestation of three factors: First, the convenience of social interaction that creates harmony and balance of life in a community; second, there is social empathy which becomes the social identity of each individual in the community, and; third, the existence of active prevention efforts from each element of the community for aggressive behavior as a trigger for violence and a source of conflict.

Based on this description, it is reasonable to say that the religious harmonization design that exists amid the Mojorejo Village community is more formed from internal desires that are strongly embedded in each member of the community and carried out steadily so that it seems to be a culture of mutual respect to maintain and preserve religious harmony

\footnotetext{
${ }^{20}$ Mr. Rujito Interview by Muhammad Yusuf, on July 16, 2020 at Mojorejo village 21 “Arti Kata Harmonisasi," KBBI Daring, BPPB Kemdikbud RI, update August 21, 2020, https://kbbi.kemdikbud.go.id/entri/harmonisasi.
}

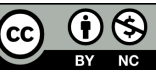

DOI: $10.19105 /$ karsa.v28i2.3777 
as to remain within the framework of harmony amid the existing plurality of community.

The integration that manifests in the harmony of the people of Mojorejo Village is a combination of several factors, as Soekanto stated that knowledge of the equality of cultural elements supported by the cultivation of tolerance, openness, and mutual respect between members of the community elements would be able to create harmony in a plural society. ${ }^{22}$ In other words, tolerance contains a concession, giving based on generosity, and bases on rights itself. This means that tolerance occurs and applies because there are differences in principles. However, these differences are address by respecting the various principles of others without sacrificing their principles.

In general, mutual respect between members of the community elements' attitude of maintaining tolerance is an urgent demand for the Indonesian people racing with the development and modernization of the times in all fields. Among the efforts that can do is enrich the insight into the values of religious teachings that emphasize tolerance. In this way, a spirit of religious tolerance can be cultivated among adherents of each religion, as has been successfully done by the community in Mojorejo village, Batu, East Java.

\section{The Origin of The Emergence of The Religious Harmony}

Religious harmonization appears as an implication of the balance of functions of religious teachings that are successfully implemented by each religious adherent or believer in their daily life. The implemen-tation of these teachings certainly does not occur as an incidental momentum but is a manifestation of the continuity of religious behaviour that obeys God's commands ${ }^{23}$, as well as a form of harmonious relationships with fellow humans and the universe. When the role of human submission to religious teachings has been able to be

\footnotetext{
22 Soerjono Soekanto, Sosiologi Suatu Pengantar (Jakarta: PT Grafindo Persada, 2010), xx.

${ }^{23}$ Hanny Hafiar, "Religious Activities of The Scavenger at The Landfill in West Java Region," Karsa: Journal of Social and Islamic Culture 27, no. 1 (2019): 149-70, https://doi.org/10.19105/karsa.v27i1.2145.
}

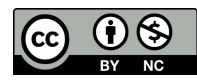

DOI: $10.19105 /$ karsa.v28i2.3777 
carried out completely, then actually the sublimation factor of religion ${ }^{24}$ has been achieved through the noble behaviour of its adherents or believers, both theologically and humanly.

Likewise, with the construct of religious harmony that grows in Mojorejo Village. The village community's behaviour, which is accustomed to humanist values among community members, eventually forms a healthy socio-cultural synergy pattern. The pattern of habituating mutual respect among the villagers is implemented naturally and is also sustainable. This continuity manifests through cooperation in three ways, namely religious, social, and cultural cooperation. Through these three combinations, viewpoints, ideas, and a social environment are born that can maintain a plurality of religions in harmony.

One of the religious cooperation carried out by the people of Mojorejo Village can be seen in the local community's interfaith prayer events. The community's interfaith prayer activity on the annual agenda in Muharram, which is routinely carried out in the Mojorejo Village area. Religious adherents live in the community gather and pray together according to their respective religions and beliefs with the same goal of praying for safety and blessings for their village. From this, it appears that the harmonization between religious believers that arises from this momentum can see as an activity that requires several essential aspects:

Firstly, the openness between the government elite and the grassroots level community is running well. This openness will necessitate or encourage dialogue between religious communities, as well as become the basis for a healthy communication process between religious adherents. This openness also what ultimately becomes the gateway for the birth of mutual trust between religious adherents or believers and leave the false tolerance behavior. In this case, the village government provides support for the implementation of programs as well as religious, social, and cultural activities initiated by the community of Mojorejo Village.

${ }^{24}$ Mukti Ali et al., Agama Dan Masyarakat: 70 Tahun H.A. Mukti Ali (Yogyakarta: IAIN Sunan Kalijaga Press, 1993), 2.

\section{(c) $\underset{\mathrm{BY}}{(\mathrm{i})(\mathrm{NC})}$}

DOI: $10.19105 /$ karsa.v28i2.3777 
Secondly, the existence of mutual understanding between the religious adherents/believers - which emerges from a mutual understanding of each religion appropriately and proportionally. Proportional knowledge will eliminate any suspicion that could potentially become the root of hostility and disharmony in religious life, and; thirdly, the recognition of religious plurality. Plurality is understood by each member of the community through active involvement to understand differences and similarities to achieve harmony in diversity. Fourthly - is the flourishing of traditional cultural ties in the community. ${ }^{25}$

Next, the social cooperation of the Mojorejo Village community is illustrated by the following explanation by Rujito as the Head of Mojorejo Village:

"The people in our village are accustomed to being friendly and helping one another in every activity carried out socially. Such as when Ashura activity therein many activities, ranging from interreligious prayer, Wayang Kulit events, village carnaval, and others. People voluntarily cooperate, starting from managing the committee to taking of the people's consumption, which is cook and enjoy together". ${ }^{26}$

Through the description, it can be said that the social cooperation carried out by each component of society in Mojorejo Village has become a habit that eventually becomes a culture. Social-community activities are carried out together by always fostering the principles of

${ }^{25}$ Lathifah Munawaroh, "Harmonisasi Antar Umat Beragama Melalui Pernikahan Beda Agama," Fikrah: Jurnal Ilmu Aqidah Dan Studi Keagamaan 5, no. 1 (2017): 197-218, https://doi.org/10. 21043/fikrah.v5i1.2307.

${ }^{26}$ Mr. Rujito Interview by Muhammad Yusuf, on July 17, 2020 at Mojorejo village.

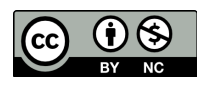

DOI: $10.19105 /$ karsa.v28i2.3777 
respect, and attention to customary regulations, as concluded by Makmur's research ${ }^{27}$, Halim ${ }^{28}$, and Aryani's research. ${ }^{29}$

This research states the findings that are different from previous studies, such as Rokhmad, who prioritizes external institutions' role in managing and maintaining the religious harmony of the plural society ${ }^{30}$, However, this research is more detailed in uncovering society's internal factors that underlie the emerge of religious harmony-plural communities. Likewise, the research conclusion states that the tolerant behavior of teachers ${ }^{31}$ and students ${ }^{32}{ }^{33}$ is the key to cultivating religious harmony in education. In detail, this article analyzes problems based on the approach socio-religious that is closely related to the construct of society in Indonesia.

Finally, cultural cooperation in Mojorejo Village, Batu, East Java can be seen from the cultural themed activities that are continuously carried out in the village. The people of Mojorejo Village

27 Testiani Makmur and Wenny Dastina, "Cultivating Local Wisdom in Character Education: Lessons from Family Education Values of Indonesian Traditional Ceremony," Walisongo: Jurnal Penelitian Sosial Keagamaan 26, no. 2 (2018): 417 444, https://doi.org/10.21580/ws.26.2.2753.

${ }^{28}$ Abdul Halim and HM Pahrudin, "The Role of Local Wisdom as Religious Conflict Resolution in Jambi Indonesia,” Walisongo: Jurnal Penelitian Sosial Keagamaan 27, no. 2 (2019): 353-74, https://doi.org/10.21580/ws.27.2.4358.

${ }^{29}$ Aryani, "Implementation of Communication Ethics in Building Social Harmony." International Journal of Social Sciences and Humanities, no. 1 (2018): 147-156, https://doi.org/10.29332/ijssh.v2n1.105.

30 Rokhmad, "The Role of Inter-Religious Harmony Forum in Maintaining The Harmony of Religious Life in Plural Society." The Social Sciences, no. 21 (2016): 5052-5059, https://doi.org/10.3923/sscience.2016.5052.5059.

${ }^{31}$ M Muslih, "Empowering Teacher of Religious Education in Multicultural Society," Walisongo: Jurnal Penelitian Sosial Keagamaan 25, no. 1 (2017): 173, https://doi.org/10.21580/ws.25.1.1213.

32 Soares and Sudarsana, "Religious Harmony Among Senior High School Students Multicultural Education Case Study in the Cova-Lima District of East Timor." Vidyottama Sanatana: International Journal of Hindu Science and Religious Studies, no. 1 (2018): 154-162, https://doi.org/10.25078/ijhsrs.v2i1.522.

33 Andi Arif Rifa'i, "Religious and Tolerant Attitudes of University Students: A Comparative Study," Walisongo: Jurnal Penelitian Sosial Keagamaan 27, no. 1 (2019): 125-48, https://doi.org/ 10.21580/ws.27.1.3872.

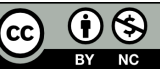

DOI: $10.19105 /$ karsa.v28i2.3777 
are closely related to Javanese culture, they always uphold this cultural tradition by carrying out a series of activities with cultural nuances. A concrete example of this cultural collaboration can be seen in the momentum of the celebration of the month of Syuro (Muharram) which is celebrated by the villagers by holding Wayang Kulit and Cultural Carnival events. Through these two activity segments, the village community volunteers to coordinate and collaborate to make the village event a success:

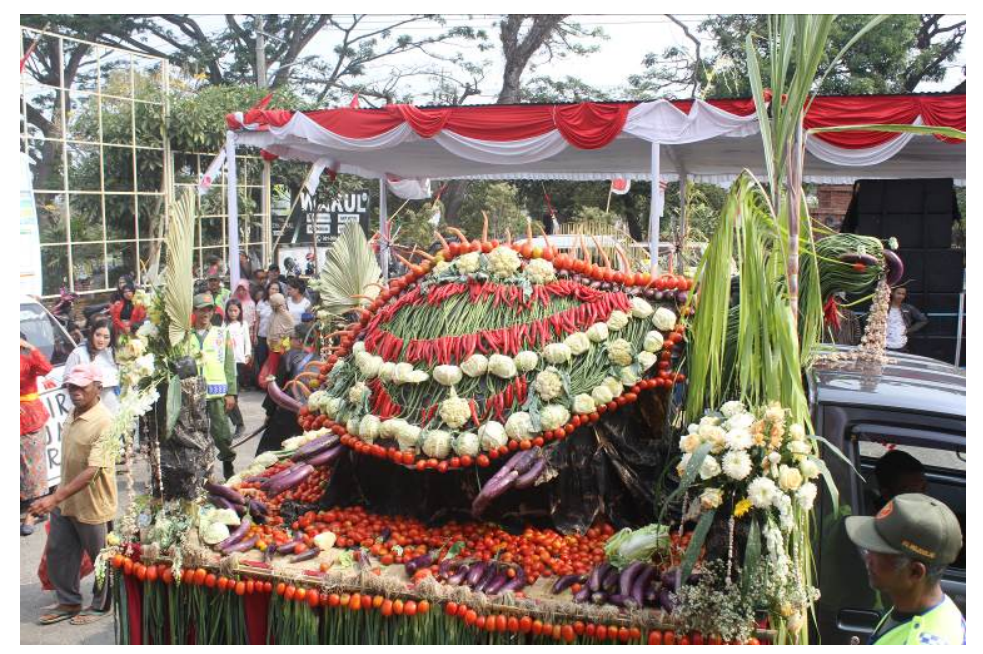

Picture 1: Cultural Carnival events in Mojorejo Village (2019)

Thus, it is common that the religious harmony that was emerged in Mojorejo Village, Batu, East Java is a social construct that is born and develops naturally and continuously in a functional-structural frame by assuming the community is an organic system that has relations between its parts to maintain the existing system.

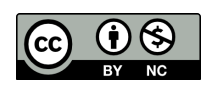

DOI: $10.19105 /$ karsa.v28i2.3777 


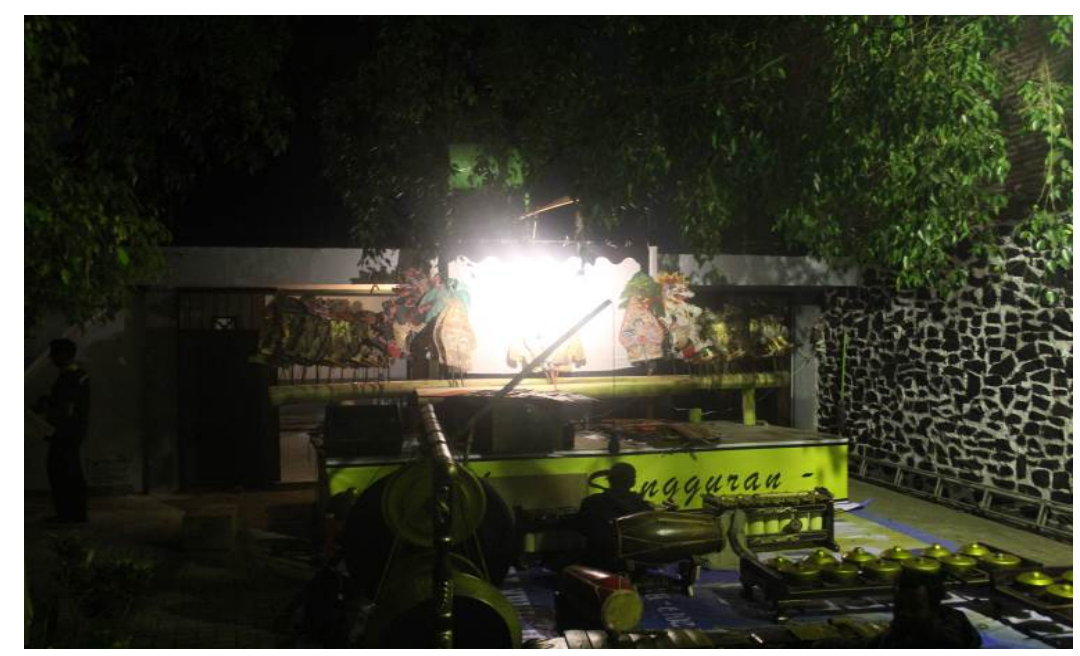

Picture 2: Wayang Kulit performance events in Mojorejo Village (2019)

\section{Conclusion}

The context of Indonesia's pluralistic community in terms of religion and belief absolutely requires real harmonization. In fact, in the long term, the harmonization of religious plurality in the midst of a pluralistic society will create unity of the society elements in a concrete and solid ways.

This research illustrates several important conclusions, namely the religious harmony construct of the Mojorejo Village community is established from a pattern of accustoming mutual respect among villagers which is carried out both naturally and sustainably. This continuity manifests through cooperation in three ways: religious, social, and cultural cooperation so that it can lead to the emerge of perspectives, ideas, and a social environment capable of maintaining and preserving religious plurality in harmony. Therefore, the application of religious harmony in Mojorejo Village, Batu, East Java can be used as an alternative solution for other areas in locating and facilitating religious plurality so that it remains harmonious amid a pluralistic community.

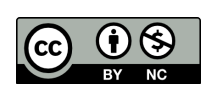

DOI: $10.19105 /$ karsa.v28i2.3777 


\section{Bibliography}

Afrian, U. "FKUB Launching Desa Sadar Kerukunan Beragama." radarmalang.id, 2019. https://radarmalang.id/fkub-launchingdesasadar-kerukunanberagama/.

Ali, Mukti, Abdurrahman, Burhanuddin Daya, and Djam'annuri. Agama Dan Masyarakat: 70 Tahun H.A. Mukti Ali. Yogyakarta: IAIN Sunan Kalijaga Press, 1993.

Aryani, Ni Luh. "Implementation of Communication Ethics in Building Social Harmony." International Journal of Social Sciences and Humanities 2, no. 1 (2018): 147-56. doi: 10.29332/ijssh. v2n1.105.

Bakar, Abu. "Konsep Toleransi Dan Kebebasan Beragama." Toleransi: Media Komunikasi Umat Bergama 7, no. 2 (2015): 123-31. doi: $0.24014 /$ trs.v7i2.1426.

Batu, Dinas Kependudukan dan Catatan Sipil Kota. "Jumlah Penduduk Menurut Kecamatan Dan Agama Yang Dianut Di Kota Batu, 2017." batukota.bps.go.id, 2019. https://batukota.bps.go.id/static table/2018/12/12/315/jumlah-penduduk-menurut-kecamatandanagama-yang-dianut-di-kota-batu-2017.html.

Casram. "Membangun Sikap Toleransi Beragama." Wawasan: Jurnal Ilmiah Agama Dan Sosial Budaya 1, no. 2 (2016): 187-98. doi: 10.15575/jw.v1i2.588.

Dinata, Muhamad Ridho. "Konsep Toleransi Beragama Dalam Tafsir Al-Qur'an Tematik Karya Tim Departemen Agama Republik Indonesia." Esensia: Jurnal Ilmu-Ilmu Ushuluddin 13, no. 1 (2012): 85-108. doi: 10.14421/esensia.v13i1.723.

Fidiyani, R. "Kerukunan Umat Beragama Di Indonesia ( Belajar Keharomonisan Dan Toleransi Umat Beragama Di Desa Cikakak, Kec. Wangon, Kab. Banyumas)." Jurnal Dinamika Hukum 13, no. 3 (2013): 468-82.

Hafiar, Hanny. "Religious Activities of The Scavenger at The Landfill in West Java Region." Karsa: Journal of Social and Islamic Culture 27, no. 1 (2019): 149-70. doi: 10.19105/karsa. v27i1. 2145.

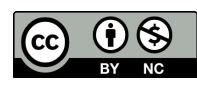

DOI: $10.19105 /$ karsa.v28i2.3777 
Halim, Abdul, and HM Pahrudin. "The Role of Local Wisdom as Religious Conflict Resolution in Jambi Indonesia." Walisongo: Jurnal Penelitian Sosial Keagamaan 27, no. 2 (2019): 353-74. doi: 10.21580/ws.27.2.4358.

Ismail, Roni. "Konsep Toleransi Dalam Psikologi Agama (Tinjauan Kematangan Beragama)." Religi 8, no. 1 (2012): 1-12. doi: 10.14421/rejusta.2012.\%25x.

Jazadi, Iwan. "The Concerns, Roots, and Challenges of Islamic Culture in Sumbawa and Their Implications for Implementing Halal Tourism." Karsa: Journal of Social and Islamic Culture 27, no. 1 (2019): 52-74. doi: 10.19105/ karsa.v27i1.2299.

Kemdikbud RI, BPPB. “Arti Kata Harmonisasi.” KBBI Daring, 2020. https://kbbi.kemdikbud.go.id/entri/harmonisasi.

Madjid, Nurcholish. Pluralitas Agama: Kerukunan Dalam Keragaman. Jakarta: Kompas, 2001.

Makmur, Testiani, and Wenny Dastina. "Cultivating Local Wisdom in Character Education: Lessons from Family Education Values of Indonesian Traditional Ceremony." Walisongo: Jurnal Penelitian Sosial Keagamaan 26, no. 2 (2018): 417-44. doi: 10.21580/ws. 26.2.2753.

Mojorejo, Arsip Desa. "Jumlah Penduduk Desa Mojorejo dan Tempat Ibadah Yang Dimiliki.” Batu, 2020.

Munawaroh, Lathifah. "Harmonisasi Antar Umat Beragama Melalui Pernikahan Beda Agama." Fikrah: Jurnal Ilmu Aqidah Dan Studi Keagamaan 5, no. 1 (2017): 197-218. doi: 10.21043/fikrah.v5i1. 2307.

Muslih, M. "Empowering Teacher of Religious Education in Multicultural Society." Walisongo: Jurnal Penelitian Sosial Keagamaan 25, no. 1 (2017): 173-202. doi: 10.21580/ws.25.1. 1213.

Pamungkas, Cahyo. "Toleransi Beragama Dalam Praktik Sosial: Studi Kasus Hubungan Mayoritas Dan Minoritas Agama Di Kabupaten Buleleng." Epistemé: Jurnal Pengembangan Ilmu Keislaman 9, no. 2 (2014): 285-316. doi: 10.21274/epis.2014.9.2.285-316.

\section{(c) (i) (s)}

DOI: $10.19105 /$ karsa.v28i2.3777 
Qowaid. "Gejala Intoleransi Beragama Di Kalangan Peserta Didik Dan Upaya Penanggulangannya Melalui Pendidikan Agama Islam Di Sekolah.” Dialog: Jurnal Penelitian Dan Kajian Keagamaan 36, no. 1 (2013): 71-86. doi: 10.47655/dialog.v36il.82.

Rifa'i, Andi Arif. "Religious and Tolerant Attitudes of University Students : A Comparative Study." Walisongo: Jurnal Penelitian Sosial Keagamaan 27, no. 1 (2019): 125-48. doi: 10.21580/ws. 27.1.3872.

Rokhmad, Abu. "The Role of Inter-Religious Harmony Forum in Maintaining The Harmony of Religious Life in Plural Society." The Social Sciences 11, no. 21 (2016): 5052-59. doi: 10.3923/sscience.2016.5052.5059.

Santiko, Hariani. "Toleransi Beragama Dan Karakter Bangsa: Perspektif Arkeologi." Sejarah Dan Budaya 7, no. 1 (2013): 1-8. doi: 10.17977/sb.v7i1.4732.

Soares, Francisco, and I Ketut Sudarsana. "Religious Harmony Among Senior High School Students Multicultural Education Case Study in the Cova-Lima District of East Timor." Vidyottama Sanatana: International Journal of Hindu Science and Religious Studies 2, no. 1 (2018): 154-62. doi: 10.25078/ijhsrs.v2i1.522.

Soekanto, Soerjono. Sosiologi Suatu Pengantar. Jakarta: PT Grafindo Persada, 2010.

Suryana, Toto. "Konsep dan Aktualisasi Kerukunan Antar Umat Beragama." Pendidikan Agama Islam -Ta'lim 9, no. 2 (2011): 127-36.

http://jurnal.upi.edu/file/03_KONSEP_DAN_AKTUALISASI_K ERUKUNAN_ANTAR_UMAT_BERAGAMA_-_TOTO.pdf.

Wijaya, Sri, Herwindya Baskara, Mursito, and Anshori, M. "Media Massa Dan Intoleransi Beragama (Studi Kasus Tentang Wacana Intoleransi Beragama Pada Surat Kabar Lokal di Kota Surakarta Tahun 2012)." Jurnal Komunikasi Massa 6, no. 2 (Juli 2013): 175-88. http://www.jurnalkommas.com/docs/Revisi\%20Jurnal\% 20Kom_UNS_Vo\%206\%20No\%202\%20Juli\%202013\%20(REV 5)-2.pdf $\#$ page $=73$.

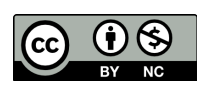

DOI: $10.19105 /$ karsa.v28i2.3777 